\title{
Assessment of solar energy potential and development in Afghanistan
}

\author{
Ahmad Tamim Mehrad** \\ People’s Friendship University of Russia (RUDN University), 117198 Moscow, Russia
}

\begin{abstract}
Energy generation in Afghanistan is limited and heavily dependent on fossil fuels and imported electricity. Due to rapid population growth and progress in the industry, services, and agriculture sectors, the existing energy sources are not fulfilling the current energy needs of the country. Meanwhile, there is a big gap between power supply and demand, which led to an energy shortage in Afghanistan. Consequently, there is a need to develop power generation and assure energy sustainability by concentrating on renewable energy sources. This paper aims to analyze the theoretical, practical, and economic potential of solar energy in Afghanistan with the main focus on PV power technology. Power generation from solar sources is theoretically, practically, and economically suitable for Afghanistan and can be a perfect solution for the energy shortage in the country. The Afghan government should consider developing solar energy as a priority for energy security, socio-economic development, and improving the quality of life in Afghanistan.
\end{abstract}

Keywords: Solar energy, Afghanistan, energy security, sustainable energy

\section{Introduction}

Energy plays a vital role in the socio-economic development of any country. Most of the human activities are directly related to the sustainable meeting of energy demands. Afghanistan is the least-developed country that has suffered from decades of war and continuous instability. One of the consequences of the long-term war and conflict in Afghanistan was the destruction of infrastructures, especially energy infrastructure [1].

Due to rapid population growth and development of industry, Afghanistan needs more amount of energy to maintain a sustainable life cycle. However, there is a severe shortage of energy supply that created an energy crisis in the country [2]. There is a big gap between electricity demand and supply that is obvious mostly during the winter and summer seasons.

At present, supplying electricity is not permanent in Afghanistan, and power outages are common that has resulted in the shutdown of power from hours to days [3]. Energy shortage and prolonged outages have not only affected the quality of life but also stagnated

\footnotetext{
* Corresponding author: ahmadtam32@gmail.com
} 
the economic development of Afghanistan [4]. The sectors such as industry, energy generation, and agriculture have been more vulnerable to power shortage, as they have experienced most economic losses in the past decade [5].

Although Afghanistan generates about one-quarter of its electricity from domestic renewable and non-renewable sources and imports nearly I GW from Uzbekistan, Tajikistan, Turkmenistan, and Iran, the country's demanded energy for cooking and heating, mostly depends on wood, charcoal, and fossil fuels [6,7].

Moreover, the dependency on fossil fuels and hazardous biomass energy sources such as coal and wood has led to increasing different environmental problems in Afghanistan as these sources are among the leading sources of air pollution in the country [8]. Afghanistan should concentrate on renewable energies to deal with an energy shortage, reduce environmental hazards and climate change effects, and reach economic development. Renewable energy sources are sustainable, environmentally friendly, economically justifiable, and clean which can play a substantial role in reducing carbon emissions and ensuring sustainable energy in Afghanistan. Among the available renewable energy sources, solar energy has the highest potential to tackle energy shortage and ensure energy sustainability in Afghanistan.

\section{Material and Method}

This paper analyses the theoretical, practical, and economic potential of solar energy in Afghanistan using the descriptive-analytical method. The statistical data and information were extracted from various reliable sources, such as the Afghanistan Ministry of Energy and Water (MEW), De Afghanistan Breshna Sherkat, National Statistics and Information Authority (NSIA), IRENA, Solargis, etc.

\section{Global status of solar energy}

In 2019, solar photovoltaic generated around $3 \%$ of the global electricity demand, and this trend tends to increase by $27 \%$ in $2050[9,10]$. Over the last decade, demand for solar PV has expanded as it became the most competitive and useful option for electricity generation in some countries. At the same time, global installed capacity has risen considerably due to the availability of free solar radiation and falling prices of photovoltaic (PV) modules. In 2019, the solar PV market had an increased rate of about $12 \%$ and reached $115 \mathrm{GW}$, whereas the total global solar PV installed capacity reached $627 \mathrm{GW}$ [11,12]. (Fig 1).

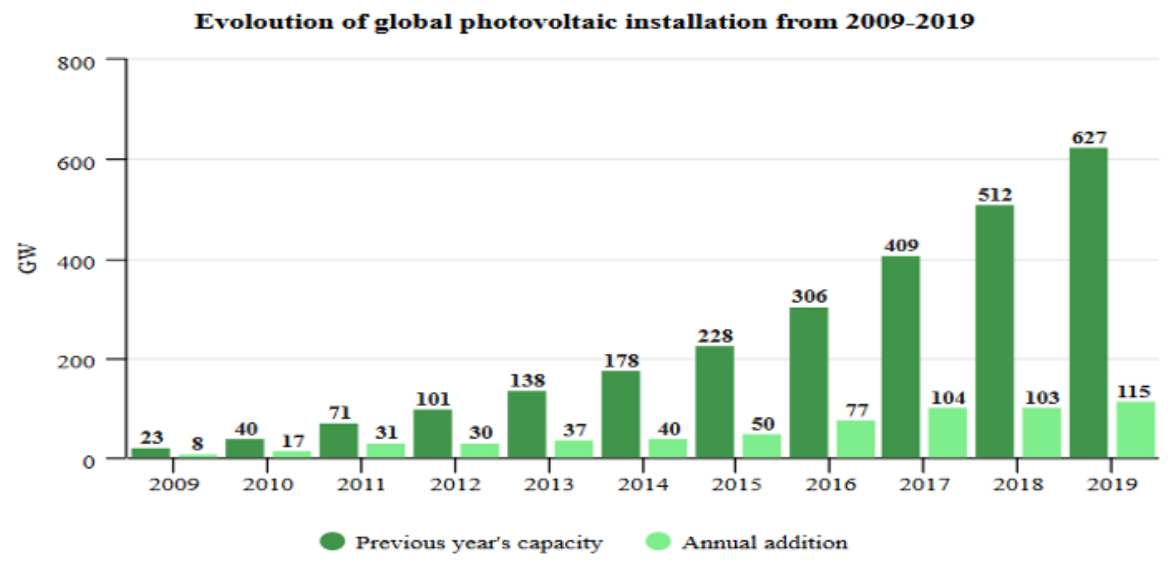

Fig. 1. The evolution of PV installed capacity from 2009-2019 
By the end of 2019, 18 countries added nearly $1 \mathrm{GW}$ of new capacity, and 39 countries had an installed cumulative capacity of more than $1 \mathrm{GW}$ [13]. Asia was the leading continent with half of the global additions, followed by Europe $17 \%$ and the Americas $15 \%$ [12]. (Fig 2). The leading countries with newly added solar PV installed capacity and their percentage share in 2019.
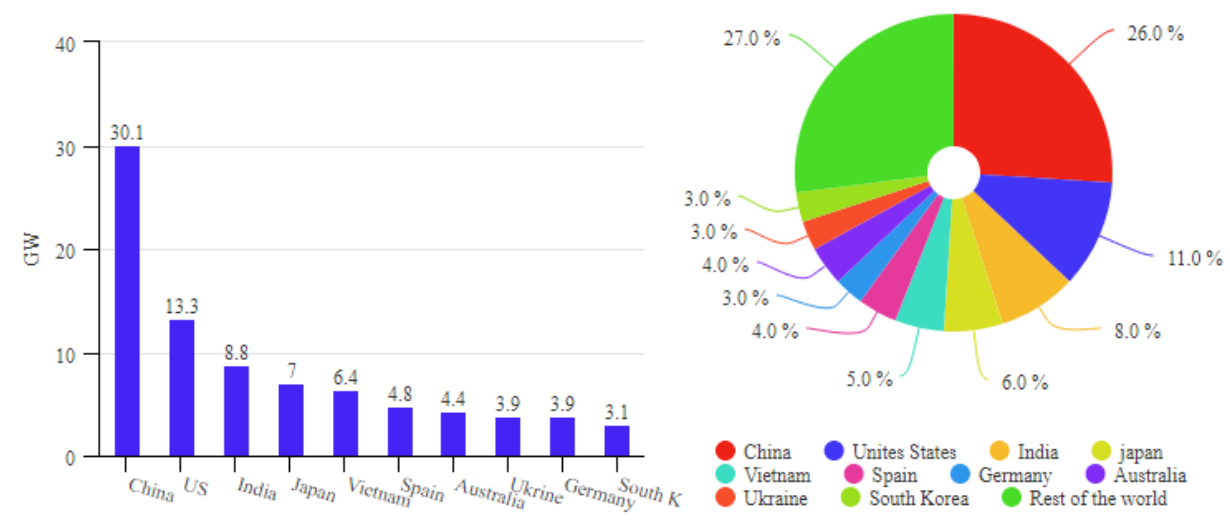

Fig. 2. Leading countries with newly added solar PV installed capacity and their percentage share [12]

It is evident from the figures that the global market's newly installed capacity was dominated by China, the traditional leader in the solar energy sector, as the country installed $30.1 \mathrm{GW}$ ( $26 \%$ of the global share). The world's largest economy, the United States, ranked second with an added capacity of $13.3 \mathrm{GW}(12 \%$ of the global share). Similarly, India, the world's fastest-growing economy, added another $9.9 \mathrm{GW}(9 \%$ of global share) and closed the gap to its assigned $100 \mathrm{GW}$ target. Despite obstacles such as limited land availability, grid constraints, and high prices of solar generation, Japan continued its stable progress with $7 \mathrm{GW}$ (6\% of global share) new additions. Rapid population growth, economic expansion, and rising electricity demand led Vietnam to install an estimated 4.8 GW (4\% of the global share). Other countries that experienced substantial additions in 2019 were Spain (4.6 GW), Germany (3.8 GW), Australia (3.7 G), Ukraine (3.5 GW), and South Korea (3.1 GW).

Although PV technology has been installed in almost all of the world's countries, the installation level was variable from a few MW to hundreds of GWs. At present, China is the global leader with a remarkable cumulative capacity of $204,7 \mathrm{GW}$, followed by the United States 75,9 GW and Japan 63 GW (Fig.3).

\section{Geography and socio-economic profile of Afghanistan}

Afghanistan is a highland and landlocked country, has an area of $652,000 \mathrm{~km}^{2}$, and located in the crossroad of Central and South Asia between $29^{\circ} 35-38^{\circ} 40^{\prime}$ latitude and $60^{\circ} 31^{\prime}$ $74^{\circ} 55^{\prime}$ of longitude [14]. It is bounded in the north by Uzbekistan, Tajikistan, and Turkmenistan, northeast with China, in south and east with Pakistan, and with Iran in the west. $82 \%$ of Afghanistan is mountainous or desert that renders communication difficult [15]. According to the World Bank estimation, Afghanistan's population is estimated at 38.041 .754 in 2019, with an annual growth rate of $2.4 \%$. More than $76 \%$ of Afghans live in rural areas and, agriculture is their most important source of income [16]. 


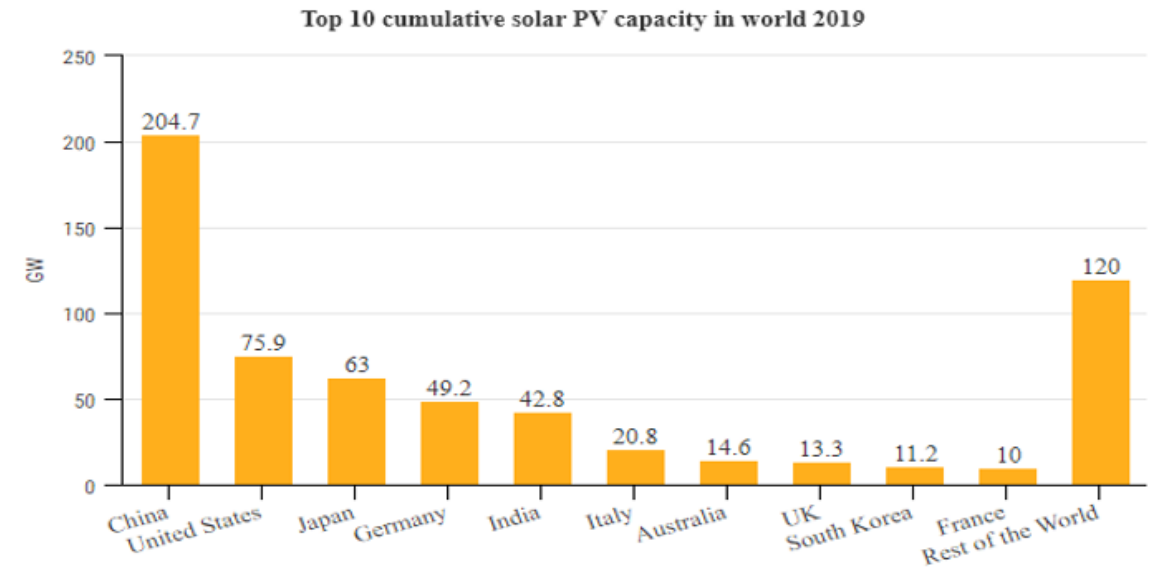

Fig. 3. Top countries with highest cumulative PV installations in 2019 [13]

According to the World Bank estimation, Afghanistan's population is estimated at 38.041 .754 in 2019, with an annual growth rate of $2.4 \%$. More than $76 \%$ of Afghans live in rural areas and, agriculture is their most important source of income [16].

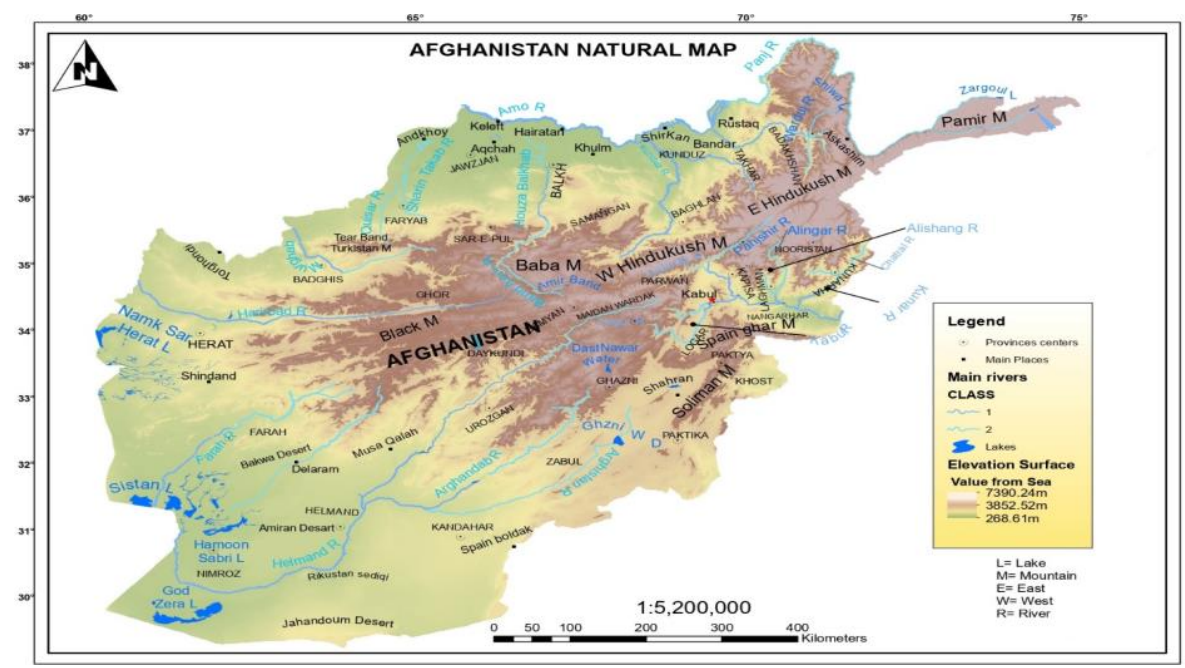

Fig. 4. Natural map of Afghanistan

In 2019, Afghanistan's gross domestic product (GDP) had a growth rate of $2.9 \%$ that was mainly guided by recovery from severe droughts and agricultural growth [17]. However, increasing security risks, political uncertainty, and the unclear future landscape continued to damp both national and international investments. Although Afghanistan has mostly been financed by grant inflows, around $61 \%$ of its population live under the national poverty line [18]. Afghanistan's poverty rate is the highest among the Central and South Asian countries and one of the highest at the global level. (Fig 5). Comparing the national poverty rate in South and Central Asian countries. 
80

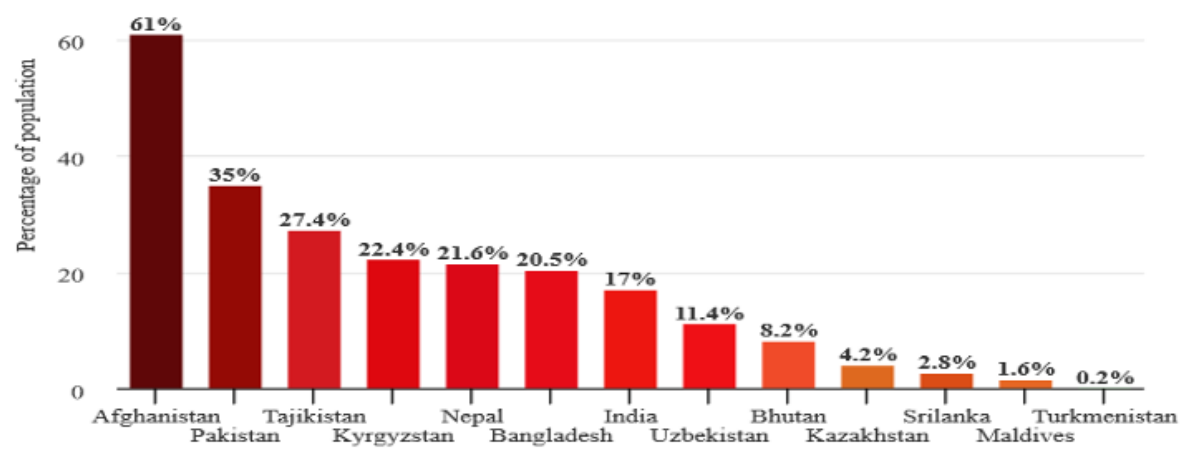

Fig. 5. Percentage of population living under the national poverty line in South and Central Asian countries, (Source: The World Bank, ADB, CIA factbook)

\section{Current energy scenario in Afghanistan}

In the past decade, Afghanistan's energy demand increased exponentially from $1500 \mathrm{MW}$ in 2010 to $3000 \mathrm{MW}$ in 2019, and it is expected that the demand increases 3-fold by 2030 and 10 -fold by 2050 [19]. The energy supply in Afghanistan is not stable and reliable due to factors such as interrupted grid networks, areas affected by conflict, and lack of investment [20]. In 2019, Afghanistan needed 3000 MW of electricity to ensure energy sustainability for both households and other sectors but, the country has been able to generate only 735 MW or $22 \%$ of the total usage and imported another 1000 MW from Tajikistan, Uzbekistan, Turkmenistan, and Iran [21]. Despite this, there is still a pressing gap of approximately $1270 \mathrm{MW}$ between supply and demand.

By the end of 2019, the country's total domestic installed capacity was $737 \mathrm{MW}$, leading by thermal sources $(42 \%)$, large hydro powers $(41 \%)$, renewables $(12 \%)$, and gaselectricity plant $(5 \%)$, while the installed capacity of transmission line for imported electricity reached 1.012 MW [22]. (Fig 6).

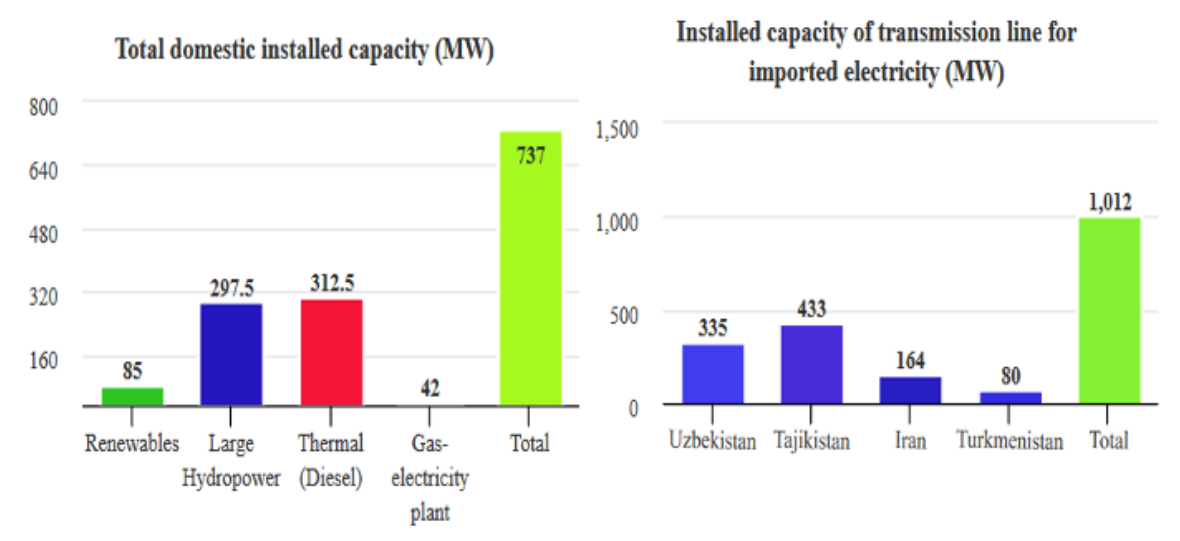

Fig. 6. Total domestic installed capacity and installed capacity of transmission line for imported electricity 
Moreover, The share of renewable sources has increased slowly from $1 \mathrm{MW}$ in 2013 to 85 MW in 2019, thanks to installing and developing solar photovoltaic and small hydro dams [23].

In Afghanistan, only $30.2 \%$ of the population has access to the national electric grid, with an access rate of approximately $88 \%$ for urban and $11 \%$ for rural households [24]. The electricity supply is not sustainable, and the level of access varies in different areas. For instance, in the capital Kabul, $95 \%$ of the population usually has access to electricity, while in Zabol province the access rate is only 37\% [25].

Roughly, $89 \%$ of electricity in Afghanistan is consumed by households, followed by industry $9 \%$ and other sectors $2 \%[26]$. The lack of access to electricity in rural areas has led to increasing poverty as more than $75 \%$ of the country's population lives in these areas, and it accounts for $67 \%$ of the gross domestic product (GDP) [27]. Afghanistan's electricity consumption is one of the lowest in the world. The country's average per capita consumption of $186 \mathrm{kWh}$ per year is significantly lower than the average Central and South Asia electric power consumption [28].

Meanwhile, high electricity tariffs have complicated affordability for households and obliged them to use traditional biomass energy resources (e.g., wood, coal, charcoal oil, and gas) for cooking and heating. Based on the energy survey of 5 major cities of Afghanistan (Kabul, Kandahar, Herat, Nangarhar, and Balkh), nearly $97 \%$ of households have used burning wood, gas, coal, charcoal, and oil for heating and cooking purposes, whereas $3 \%$ used electricity for heating and cooking [26].

Table.1. Energy consumption pattern in 5 major cities of Afghanistan

\begin{tabular}{lccccccc}
\hline \hline City & Electricity & Oil & Gas & Wood & Coal & Charcoal & Other sources \\
& & & & & & & \\
Kabul & $4.8 \%$ & $5.3 \%$ & $42.4 \%$ & $23.2 \%$ & $14.4 \%$ & $8.3 \%$ & $1.6 \%$ \\
Herat & $5.6 \%$ & $3.1 \%$ & $49.3 \%$ & $20.9 \%$ & $8.4 \%$ & $7.5 \%$ & $5 \%$ \\
Kandahar & $1.3 \%$ & $5.7 \%$ & $29 \%$ & $32.4 \%$ & $12.8 \%$ & $14.4 \%$ & $4.2 \%$ \\
Nangarhar $1.6 \%$ & $3.9 \%$ & $31.7 \%$ & $34,6 \%$ & $10.9 \%$ & $12.6 \%$ & $4.7 \%$ \\
Balkh & $5.7 \%$ & $3.2 \%$ & $38.8 \%$ & $26 \%$ & $16.1 \%$ & $9.2 \%$ & $1 \%$ \\
\hline
\end{tabular}

The extensive use of biomass energy sources in these five cities indicates that Afghanistan is unable to supply clean energy for cooking and heating. The high energy deficit for cooking and heating put Afghanistan among the world's 20 countries with the cleanest cooking access deficit [29].

\section{Solar energy in Afghanistan}

Solar energy is a renewable energy that uses the light and heat of the sun to produce electrical or thermal energy. It is clean and cheap energy that is accessible almost anywhere in the world. In Afghanistan, solar energy has traditionally been using for water heating. For the first time in 2005, rooftop PV was used in the Bamian province to provide electricity to rural communities [30]. Today, both PV and solar thermal technologies are available in Afghanistan, and they play a vital role in supplying electricity to rural communities. In addition to generating electricity, solar thermal energy is mostly using in applications such as solar stoves, solar dryers, and solar water heaters in the country. 


\subsection{Theoretical solar PV potential}

The utilization of solar energy yield is related to the distribution of the solar resource in locations where there is potential for power generation. Theoretical assessment of the Afghanistan territory by NREL indicated that the country is situated in the sunbelt with 300 days of sunshine each year and abundant solar energy [31]. Afghanistan's Direct Normal Irradiation (DNI) ranges from 3.38 to $7 \mathrm{kWh}$ per $\mathrm{m}^{2}$ and, Global Horizontal Irradiance or GHI) is estimated at 4.0 to $6.0 \mathrm{kWh}$ per $\mathrm{m}^{2}$ per day [32]. It suggests that every $10 \mathrm{~m}^{2}$ of the country's territory can generate $1 \mathrm{~kW}$ of solar energy, specifically through solar PV technology [33]. Higher values prevail in the southern and western provinces of Helmand, Kandahar, Herat, Farah, and Nimroz as they have more than 3400 sunny hours. The northern provinces with irradiance averages of $4.5 \mathrm{kWh}$ per $\mathrm{m}^{2}$ per day also have the technical and economic potential of generating electricity. (Fig 7).

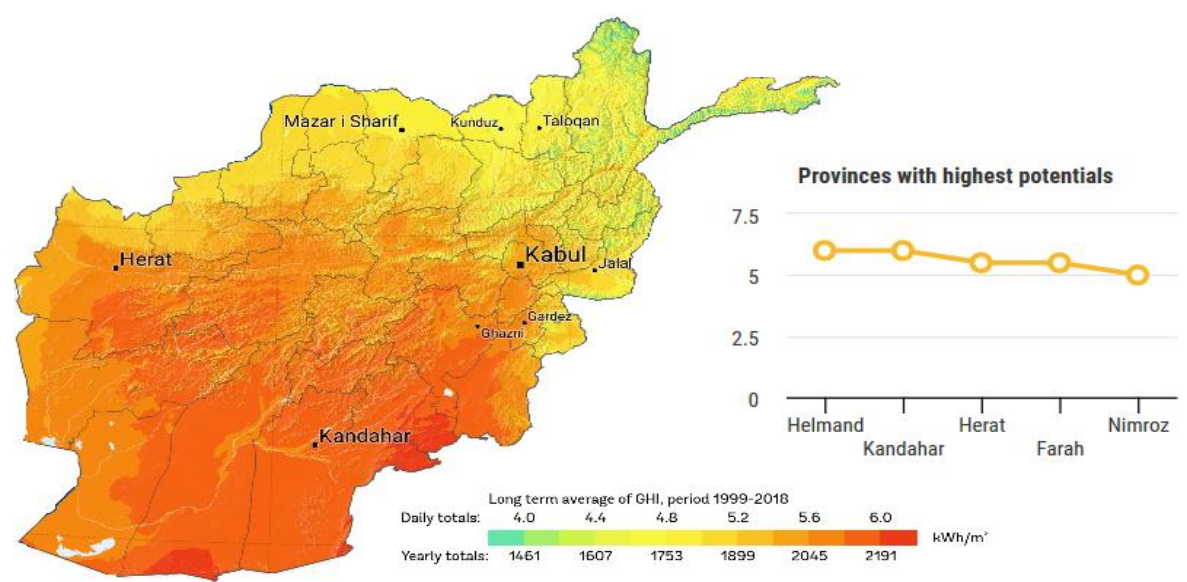

Fig. 7. GHI Map of Afghanistan and provinces with the highest values of solar potentials.

Considering the continental climate of Afghanistan, GHI's highest value is available from April to October that is favorable for maximum power generation. From April to October, the average GHI in five provinces with the highest values is nearly $6.2 \mathrm{kWh}$ per $\mathrm{m}^{2}$ per day, while it decreases to an average of $3.7 \mathrm{kWh}$ per $\mathrm{m}^{2}$ per day on the other months. (Fig 8).

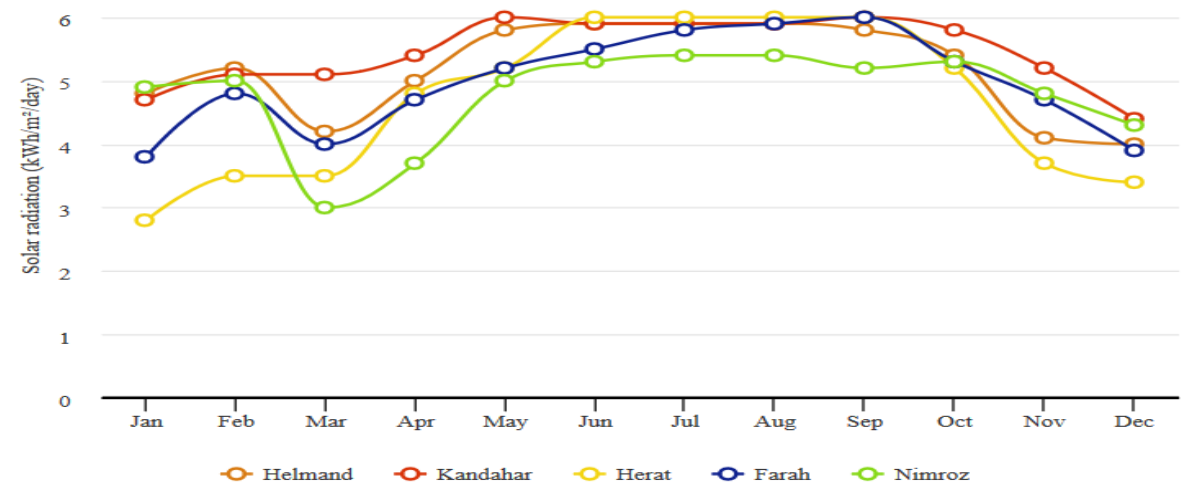

Fig. 8. Monthly GHI of Afghanistan's high-value provinces 
Afghanistan's total solar energy potential, based on both solar radiation and the suitable area, is estimated at 222,849 MW [33]. Helmand province, with an estimated 33,282 MW, has the highest solar energy capacity in the country, whereas Kapisa in the north, with 183 MW, has the lowest capacity [34]. (Fig 9).

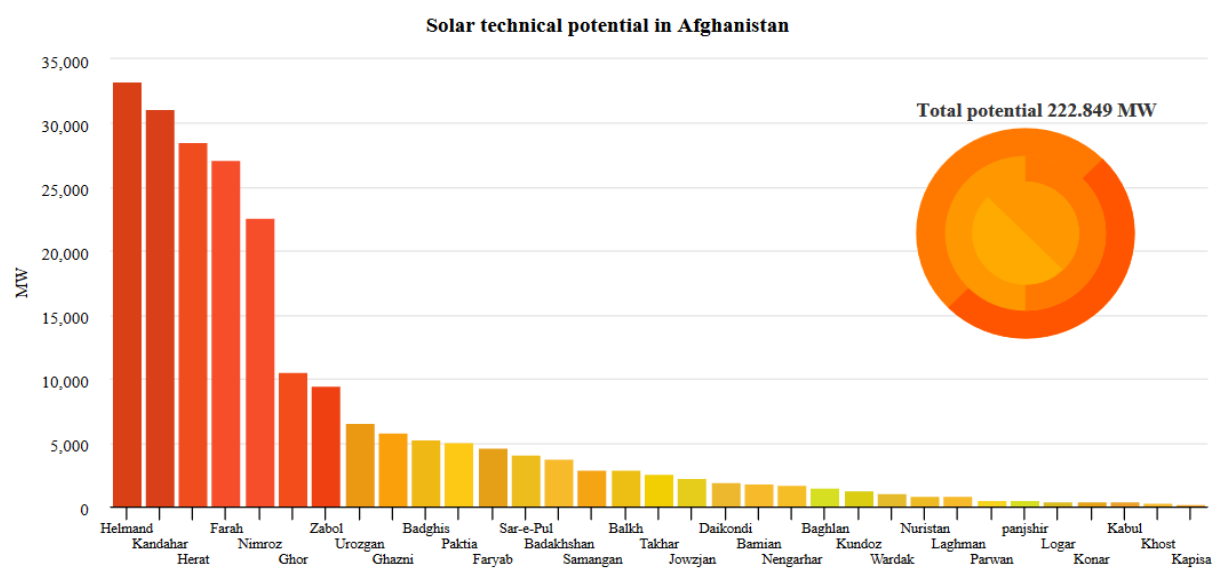

Fig. 9. Solar technical potentials in Afghanistan provinces

\subsection{Practical Solar PV Potential}

Nowadays, PV technology is the most suitable way of converting solar radiation into electricity. The practical PV utilization and power output are achievable by the PV system. PV power plants are available in almost all countries and steadily become a dominant source of electricity generation in the world. Suitability and efficiency of PV potential and conversion are mostly determined by factors such as air temperature, terrain elevation, latitude, clouds, and shading.

The long-term yearly average temperature in Afghanistan is 12 to $14{ }^{\circ} \mathrm{C}$. The figures reach 18 in the southern and western zones, 16 to $18^{\circ} \mathrm{C}$ in eastern, 10 to $12{ }^{\circ} \mathrm{C}$ in northern, and 6-8 ${ }^{\circ} \mathrm{C}$ in central provinces respectively, which suggests that the country's air temperature is suitable for PV utilization [35]. Moreover, Afghanistan's strong solar radiation, topography, and clear sky with limited cloud availability provide a favorable ground for solar PV installation. Despite some seasonal fluctuations in the country, the average seasonality index is below 2.0, and PVOUT exceeds $4 \mathrm{kWh}$. It indicates that solar PV has the highest capacity to meet a significant share of Afghanistan's current and future energy demand.

At present, Afghanistan produces some $40 \mathrm{MW}$ of electricity through solar power plants [23]. The first solar power plant was built in Bamyan province with the aid of The New Zealand government and capacity of 1,03 MW, followed by solar PV and wind hybrid in Herat with a capacity of $2 \mathrm{MW}$ and a solar plant in Kandahar which has a capacity of 30 MW [25]. 


\subsection{The Economic PV Potential}

The economic suitability of PV installation is mostly assessed by considering the expenditures to produce a unit of energy from PV sources compared to other energy generation sources. This includes factors such as the cost of the PV panels and technology, pay-out, overall capital investment, operation and maintenance costs, environmental effects, and PV's potential to compete with other forms of energy. In 2019, the lowest cost for installing PV was in India and China, as they are the manufacturing hub of this system and have low installation and maintenance costs.

There are different ways to assess the economic potential of the PV system, but one of the most practical ways is the Levelized Cost of Electricity (LCOE) [37]. LCOE can be used to compare various power generation technologies, including both renewables and non-renewables. By defining LCOE and calculating PVOUT using the below suggested equation of IRENA, the LCOE value of solar PV in a particular country can be calculated.

$$
L C O E=\frac{\sum_{t=1}^{n} \frac{C A P E X_{t}+O P E X_{t}}{(1+d)^{t}}}{\sum_{t=1}^{n} \frac{P V O U T_{t}}{(1+d)^{t}}}
$$

In which;

LCOE $=$ The average lifetime Levelized cost of electricity generation

CAPEX = Investment expenditures in the year $\mathrm{t}$

OPEX = Operations and maintenance costs in the year $\mathrm{t}$

PVOUTt $=$ Electricity generation in the year $\mathrm{t}$

$\mathrm{d}=$ Discount rate

$\mathrm{n}=$ Lifetime of the PV system in years

By using the available data from IRENA, Afghanistan Ministry of Energy and Water, and researching in the Afghanistan local market, the LCOE calculated for large scale PV plants in Afghanistan considering 25 year warranty period. The results are presented in Table 2.

Table 2. Estimation of LCOE, grid-connected and off-grid solar system in Afghanistan

\begin{tabular}{|l|l|l|}
\hline LCOE & $\begin{array}{l}\text { The cost of a grid-connected } \\
\text { solar PV system }\end{array}$ & $\begin{array}{l}\text { The cost of the off-grid solar } \\
\text { PV system }\end{array}$ \\
\hline $0.05 \mathrm{kWh}$ & $864 \$ \mathrm{kWp}$ & $1344 \$ \mathrm{kWp}$ \\
\hline
\end{tabular}

The calculation of the average cost of electricity generation by source in Afghanistan, considering the average cost of these sources in 2019, indicated that solar PV is the second cheapest source for generating electricity after onshore wind. (Fig 10.)

The economic evaluation of PV expenditures in the Afghanistan market, including the cost of the PV system, custom taxes, transportation, availability of systems, costs of installing power plants, and rooftop PV, indicated that the market dominates by cheap and widely accessible Chinese and Indian PV systems. Besides that, there is a reasonable cost of installation, transportation, and maintenance. The construction and operation cost of a typical PV power plant in Afghanistan has been calculated at $\$ 0.05$ per $\mathrm{kWh}$, which shows justifiable investment capacity with future cash flows. 


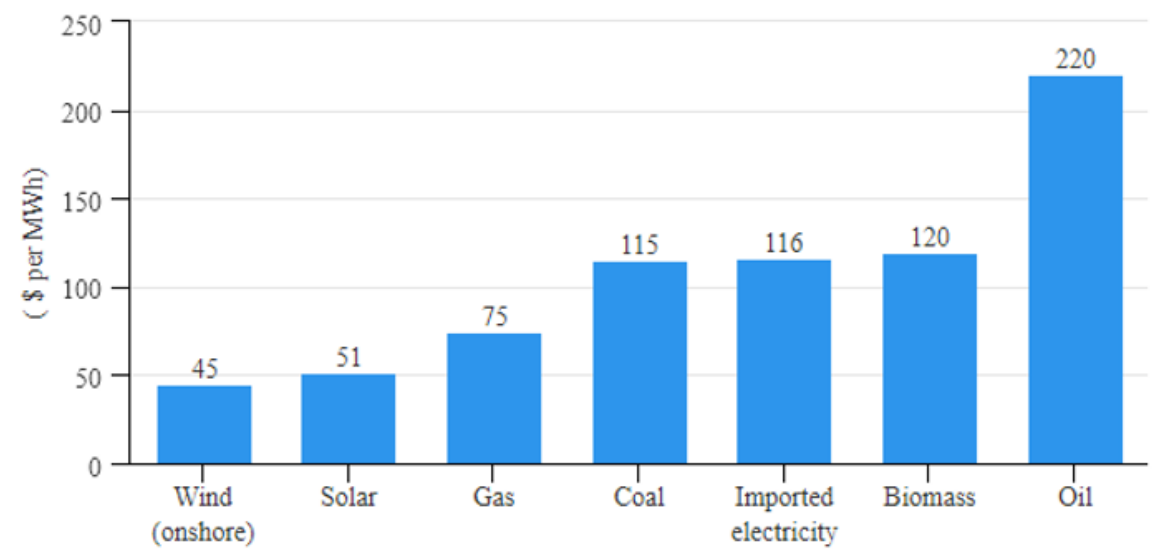

Fig 10. The average cost of electricity by the source in Afghanistan ( Source: author's calculation)

In the last decade, Afghanistan's solar energy market has experienced two main trends. Firstly, the growing trend of solar energy production, particularly rooftop PV, and secondly, the continuous reduction of the production cost.

Furthermore, air pollution and environmental problems relevant to biomass energy consumption have imposed substantial costs on the government and, consequently, the people of Afghanistan. The utilization of renewable energy, especially solar energy, can be important for both the economy and the environment of the country, as solar PV is clean and cost-competitive in Afghanistan, where electricity generation is dominated by polluting diesel, thermal generators, and high tariffs.

Although power generation from solar systems tends to be quite useful for Afghanistan, it also has some economic barriers that affected the development of this technology. The main barriers can be listed as follows;

- Solar energy projects require high capital investment and a long time for cashback.

- There is limited government support and subsidies for solar projects.

- Banks in Afghanistan are not interested in supporting big projects.

- There are financial risks associated with the performance of solar energy projects.

\section{Conclusion}

Energy is the cornerstone of the socio-economic development of a country. Afghanistan, like other least developed countries, relies on traditional fossil fuels and electricity imports to meet its energy requirements. Due to the limitation of energy sources and a big gap between supply and demand, Afghanistan has faced an energy crisis that has negatively affected the socio-economic development of the country. On the other hand, the lack of clean and sustainable energy has impelled Afghans to use traditional biomass energy sources.

Afghanistan has significant solar energy potential that can be considered the most useful option for improving energy security and ensuring energy sustainability in the country. Solar photovoltaic (PV) has the theoretical, practical, and economic potential to be the leading source of energy in Afghanistan.

The distribution of solar resources in Afghanistan indicates that all over the country has the capacity for installing PV technology with the highest potential in the southern and western provinces of Helmand, Kandahar, Herat, Farah, and Nimroz, as they have an 
overall capacity of $142.568 \mathrm{MW}$ or $64 \%$ of the total potential of the country. Furthermore, direct radiation, clear sky, optimum temperature, and terrain provide the practical ground for PV installation. The cost of PV technology and services is reasonable in Afghanistan but, the lack of capital investment in the big PV projects has remained a barrier against the development of this energy in the country.

\section{References}

1. Asian Development Bank; Energy is Life Bringing Power to Afghanistan (2010)

2. The World Bank, Afghanistan Renewable Energy Development Issues and Options (2018)

3. Afghanistan in 2019: A Survey of Afghan People, (Asia Foundation, 2018)

4. Z. Taniwal, Economic Geography of Afghanistan, Maiwand Press, Kabul, 13 (2014)

5. A. Korkovelos, M. Bazilian, D. Mentis, M. Howells, A GIS Approach to Planning Electrification in Afghanistan (2017)

6. D. Gencer. J. Irving, P. Meier, R. Spencer, C. Wnuk, Energy Security Trade-offs Under High Uncertainty: Resolving Afghanistan's Power Sector Development Dilemma (2008)

7. U. Paudel, U. Khatri, K. P. Pant, Ene, 156, 55-62 (2018)

8. Afghanistan Ministry of Public Health, Outdoor Air Pollution Report (2016)

9. Snapshot of Global PV Markets 2020, IEA PVPS/ Report IEA-PVPS T1-37 (2020)

10. Future of Solar Energy: An interdisciplinary MIT Study (2015)

11. Renewable capacity statistics 2020, International Renewable Energy Agency (IRENA) (2020)

12. REN21. Renewables 2020 Global Status Report (2020)

13. Global Market Outlook for Solar Power 2020-2024 (2020)

14. Z. Taniwal, Physical Geography of Afghanistan, 8 (2014)

15. K. Safi, Kup, 14, 45-58 (2006)

16. NSIA, Afghanistan Central Statistical Yearbook 2019 (2019)

17. International Monetary Fund: IMF Country Report No.20/143 (Islamic Republic of Afghanistan) (2020)

18. Afghanistan Ministry of Labour and Social Affairs, 2018 report (2018)

19. Afghanistan Power Sector Master Plan (2013)

20. S. Ahmadzai, A. McKinna, Ene Rep, 4, 435-469 (2018)

21. Afghanistan Ministry of Energy and Water, Quarterly Report no 4 (2019)

22. Afghanistan Ministry of Energy and Water, Electricity Production Report 2019 (2019)

23. MEW, Renewable Energy Department, Renewables Development (2020)

24. De Afghanistan Breshna Sherkat, Electricity Access in Afghanistan (2018)

25. De Afghanistan Breshna Sherkat, Electricity Assessment Unit (2020)

26. Socio-economic Survey of Energy Accessibility in Afghanistan, Vol 1 (2020)

27. Afghanistan Ministry of Rural Rehabilitation and Development, Sustainable Energy for Rural Development (2019)

28. Afghanistan Ministry of Rural Rehabilitation and Development, Rural Off-grid Electrification in Afghanistan (2018) 
29. IEA, IRENA, UNSD, WB, WHO, Tracking SDG 7: The Energy Progress Report (2019)

30. S. R. Hasani, Bup, 4, 13-18 (2008)

31. D. S. Renne, M. Kelly, D. Elliott, R. George, G. Scott, S. Haymes, D. Heimiller, A. Milbrandt, S. Cowlin, P. Gilman, R. Perez, Solar and Wind Resource Assessments for Afghanistan and Pakistan, Proceedings of ISES World Congress 2007, Vol 1-4, 134140 (2008)

32. Global Solar Atlas/ Solargis Afghanistan, (Accessed on 15 April 2020)

33. Renewable Energy Department, Solar Resources Landscape of Afghanistan, (2016)

34. Renewable Energy Roadmap for Afghanistan: RER2032 (2019)

35. G. J. Arez, General Climatology of Afghanistan, Kabul University Press, 48 (2007)

36. Enabling PV Afghanistan 2017: Institutional Development for Energy in Afghanistan (IDEA) Programme (2017)

37. IRENA 2019: Renewable power generation cost report 2018, (2019) 